Popovych Igor L., Gozhenko Anatoliy I., Kuchma Igor L., Zukow Walery, Bilas Volodymyra R., Koval'chuk Galyna Y., Ivasivka Anzhela S. Immunotropic effects of so-called slag metabolites (creatinine, urea, uric acid and bilirubin) at rats. Journal of Education, Health and Sport. 2020;10(11):320-336. eISSN 2391-8306. DOI http://dx.doi.org/10.12775/JEHS.2020.10.11.033 https://apcz.umk.pl/czasopisma/index.php/JEHS/article/view/JEHS.2020.10.11.033

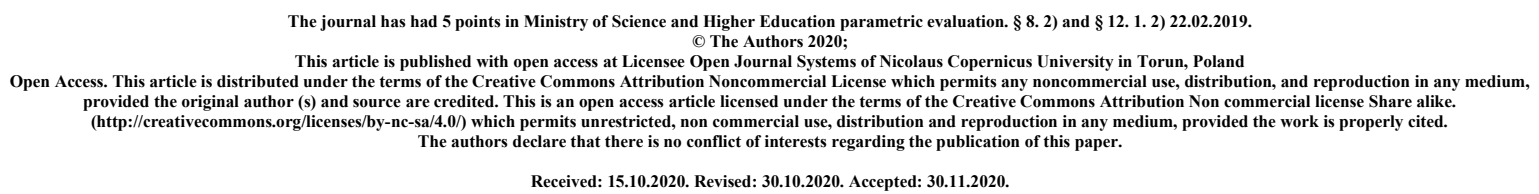

\title{
IMMUNOTROPIC EFFECTS OF SO-CALLED SLAG METABOLITES (CREATININE, UREA, URIC ACID AND BILIRUBIN) AT RATS
}

\author{
Igor L. Popovych ${ }^{1,3}$, Anatoliy I. Gozhenko ${ }^{1}$, Igor L. Kuchma ${ }^{1}$, Walery Zukow ${ }^{2}$, \\ Volodymyra R. Bilas ${ }^{3}$, Galyna Y. Koval'chuk ${ }^{4}$, Anzhela S. Ivasivka ${ }^{4}$ \\ ${ }^{1}$ Ukrainian Scientific Research Institute for Medicine of Transport, Odesa, Ukraine \\ prof.gozhenko@gmail.com; igorkuchma@ukr.net \\ ${ }^{2}$ Nicolaus Copernicus University, Torun, Poland w.zukow@wp.pl \\ ${ }^{3}$ Bohomolets' OO Institute of Physiology of National Academy of Sciences, Kyïv, \\ Ukraine i.popovych@biph.kiev.ua \\ ${ }^{4}$ Ivan Franko Pedagogical University, Drohobych, Ukraine \\ galynakovalchuk5@gmail.com
}

\begin{abstract}
Background. The study of the effect of end products of protein and nucleic acid metabolism on the immune system is of interest not only theoretical but also practical in line with the problems of urotoxins and hemodialysis. In previous studies, we found significant links between uricemia and uricosuria, on the one hand, and immune parameters, on the other hand. In this study, the spectrum of nitrogenous metabolites was expanded due to creatinine, urea and bilirubin. Material and methods. Experiment was performed on 60 healthy female Wistar rats. The plasma level and urinary excretion of the nitrogenous metabolites were determined. Immune status was assessed by thymocytogram, splenocytogram, blood leukocytogram and immunocytogram, as well as phagocytosis of blood neutrophils and monocytes. Results. Both negative and positive metabolic-immune correlations were revealed. Calculation of multiple correlation coefficients between individual metabolite parameters and constellations of immune parameters revealed the maximum immunotropic effect of uricosuria $(\mathrm{R}=0,637)$. This is followed by excretion of urea $(\mathrm{R}=0,617)$ and creatinine $(\mathrm{R}=0,606)$, bilirubinemia $(\mathrm{R}=0,589)$, creatinineemia $(\mathrm{R}=0,567)$, uricemia $(\mathrm{R}=0,566)$ and plasma urea level $(\mathrm{R}=0,500)$. The canonical correlation between the constellation of nitrogenous metabolites, on the one hand, and the parameters of immunity, on the other hand, was very strong: $\mathrm{R}=0,921 ; \chi_{(154)}^{2}=282 ; \mathrm{p}<10^{-6}$. Conclusion. Nitrogen metabolites exhibit significant immunotropic activity, both suppressor and enhancing.
\end{abstract}

Key words: uric acid, creatinine, urea, bilirubin, immunity, relationships, rats. 


\section{INTRODUCTION}

The study of the effect of end products of protein and nucleic acid metabolism on the immune system is of interest not only theoretical but also practical in line with the problems of urotoxins and hemodialysis. In previous studies, we found significant links between uricemia and uricosuria, on the one hand, and immune parameters, on the other hand, in both healthy rats [17,18] and patients in Truskavets' spa [19,20,37]. In this experimental study, the spectrum of nitrogenous metabolites was expanded due to creatinine, urea and bilirubin.

\section{MATERIAL AND METHODS}

Experiment was performed on 60 healthy female Wistar rats 240-290 g. Of these, 10 remained intact, while others received drinking water of various compositions during the week. The day after the completion of the drinking course in all rats, at first, a sample of peripheral blood (by incision of the tip of the tail) was taken for leukocytogram analysis. Animals were then placed in individual chambers with perforated bottom for collecting daily urine. The experiment was completed by decapitation of rats in order to collect as much blood as possible.

The plasma level of the nitrogenous metabolites were determined: creatinine (by Jaffe's color reaction by Popper's method), urea (urease method by reaction with phenolhypochlorite), uric acid (uricase method) and bilirubin (by diazoreaction using the Jedrashik-Kleghorn-Grof method). The same metabolites, with the exception of bilirubin, were also determined in the daily urine. The analyzes were carried out according to the instructions described in the manual [15]. The analyzers "Pointe-180" ("Scientific", USA) and "Reflotron" (Boehringer Mannheim, BRD) were used with appropriate sets.

In the blood, the parameters of immunity were determined as described in the manual [31]: the relative content of the population of T-lymphocytes in a test of spontaneous rosette formation with erythrocytes of sheep by Jondal M et al [24], their theophylline-resistant (Thelper) and theophyllin-sensitive (T-cytolytic) subpopulations (by the test of sensitivity of rosette formation to theophylline by Limatibul S et al [26]; the population of B-lymphocytes by the test of complementary rosette formation with erythrocytes of sheep by Bianco C [5]. Natural killers were identified as large granules contain lymphocytes.

About the state of the phagocytic function of neutrophils (microphages) and monocytes (macrophages) were judged by the phagocytary index, the microbial count and the killing index for Staphylococcus aureus (ATCC N25423 F49) [6,11].

Immune organs weighed and made smears-imprints for counting splenocytogram and thymocytogram $[3,4,6]$. For them, as well as leukocytogram, CE Shannon's entropy was calculated [33].

Digital material is statistically processed on a computer using the software package "Statistica 20".

\section{RESULTS AND DISCUSION}

According to calculations by the formula: $|\mathrm{r}|=\left\{\exp \left[2 \mathrm{t} /(\mathrm{n}-1,5)^{0,5}\right]-1\right\} /\left\{\exp \left[2 \mathrm{t} /(\mathrm{n}-1,5)^{0,5}\right]+1\right\}$

for a sample of $n=60$ critical value $|r|$ at $p<0,05(t>2,00)$ is 0,25 , at $\mathrm{p}<0,02(t>2,39)$ is 0,30 , at $\mathrm{p}<0,01(\mathrm{t}>2,66)$ is 0,33 , at $\mathrm{p}<0,001(\mathrm{t}>3,46)$ is 0,42 .

Screening of linear correlation coefficients between parameters of nitric metabolites, on the one hand, and the recorded parameters of immunity, on the other hand, revealed the following (Table 1). The table does not include registered immunity parameters, which did not reveal any noteworthy correlation coefficient with nitrogenous metabolites. The general impression is that along with the expected negative correlations, there are positive correlations. 
In the next step of the analysis, a regression model was constructed for each plasma and urine nitrogen metabolite by stepwise exclusion until the maximum level of adjusted $\mathrm{R}^{2}$ was reached. As a result, it turned out that some regression models included parameters with an insignificant correlation coefficient, while some parameters with a significant correlation were outside the model.

Now let's analyze each regression model.

From the regression model it follows that creatinineemia upregulates the relative content in the blood of theophylline-resistant T-lymphocytes and the relative mass of the spleen, while downregulates the content of reticulocytes in the thymus and the entropy of the leukocytogram. Judging by adjusted $\mathrm{R}^{2}$, the rate of immunomodulation is $27,2 \%$ (Table 2 and Fig. 1).

Table 1. Correlation matrix for metabolic and immune parameters

\begin{tabular}{|c|c|c|c|c|c|c|c|}
\hline \multirow[b]{2}{*}{ Variables } & \multicolumn{7}{|c|}{ Correlations } \\
\hline & CrEx & $\mathrm{CrP}$ & UreaEx & UAEx & Bilir & UreaP & UAP \\
\hline Creatinine Excretion & 1,00 & 0,04 & 0,59 & 0,39 & 0,04 & 0,14 & 0,15 \\
\hline Creatinine Plasma & 0,04 & 1,00 & 0,08 & 0,13 & 0,25 & 0,84 & $-0,28$ \\
\hline Urea Excretion & 0,59 & 0,08 & 1,00 & 0,35 & 0,27 & 0,16 & 0,12 \\
\hline Uric Acid Excretion & 0,39 & 0,13 & 0,35 & 1,00 & 0,13 & 0,06 & 0,48 \\
\hline Bilirubin Plasma & 0,04 & 0,25 & 0,27 & 0,13 & 1,00 & 0,25 & $-0,16$ \\
\hline Urea Plasma & 0,14 & 0,84 & 0,16 & 0,06 & 0,25 & 1,00 & $-0,31$ \\
\hline Uric Acid Plasma & 0,15 & $-0,28$ & 0,12 & 0,48 & $-0,16$ & $-0,31$ & 1,00 \\
\hline Leukocytogram Entropy & $-0,06$ & $-0,26$ & $-0,17$ & 0,00 & $-0,19$ & $-0,19$ & 0,24 \\
\hline Thymocytogram Entropy & $-0,01$ & $-0,06$ & $-0,25$ & $-0,25$ & $-0,04$ & 0,22 & $-0,19$ \\
\hline Splenocytogram Entropy & 0,08 & 0,23 & 0,12 & $-0,10$ & 0,27 & 0,21 & $-0,15$ \\
\hline Microbial Count Neutrophils & $-0,23$ & 0,14 & 0,07 & 0,53 & 0,28 & $-0,06$ & 0,25 \\
\hline Phagocytic Index Monocytes & 0,19 & $-0,17$ & $-0,05$ & 0,06 & $-0,09$ & $-0,23$ & 0,05 \\
\hline Phagocytic Index Neutrophils & $-0,08$ & 0,13 & 0,20 & 0,30 & 0,18 & 0,13 & 0,09 \\
\hline Spleen Mass Index & 0,25 & 0,30 & 0,08 & 0,00 & $-0,10$ & 0,24 & $-0,03$ \\
\hline Lymphoblastes Spleen & $-0,09$ & 0,01 & 0,40 & 0,11 & 0,42 & $-0,03$ & 0,05 \\
\hline Lymphocytes Spleen & $-0,16$ & $-0,23$ & $-0,03$ & $-0,02$ & $-0,11$ & $-0,28$ & 0,12 \\
\hline Plasmocytes Spleen & $-0,28$ & 0,22 & 0,15 & $-0,01$ & 0,42 & $-0,03$ & $-0,11$ \\
\hline Fibroblastes Spleen & 0,40 & 0,15 & 0,14 & 0,20 & $-0,03$ & 0,17 & 0,13 \\
\hline Microphages Spleen & $-0,18$ & 0,04 & $-0,22$ & $-0,08$ & $-0,22$ & 0,08 & $-0,01$ \\
\hline Eosinophiles Spleen & 0,02 & $-0,05$ & $-0,22$ & $-0,35$ & $-0,21$ & $-0,05$ & $-0,10$ \\
\hline Thymus Mass Index & $-0,03$ & 0,09 & $-0,24$ & $-0,05$ & $-0,19$ & 0,14 & $-0,13$ \\
\hline Lymphocytes Thymus & 0,03 & 0,12 & 0,34 & 0,29 & 0,11 & $-0,12$ & 0,18 \\
\hline Lymphoblastes Thymus & $-0,30$ & 0,07 & $-0,04$ & 0,00 & 0,14 & $-0,05$ & $-0,18$ \\
\hline Reticulocytes Thymus & 0,06 & $-0,24$ & $-0,11$ & $-0,26$ & $-0,16$ & $-0,08$ & 0,12 \\
\hline Epitheliocytes Thymus & $-0,01$ & $-0,20$ & $-0,45$ & $-0,29$ & $-0,33$ & $-0,12$ & $-0,0 s$ \\
\hline Endotheliocytes Thymus & 0,01 & 0,13 & 0,01 & 0,08 & 0,19 & 0,27 & 0,04 \\
\hline Macrophages Thymus & 0,24 & 0,07 & 0,31 & 0,18 & 0,14 & 0,21 & $-0,05$ \\
\hline Hassal's corpuscles Thymus & 0,07 & 0,08 & $-0,07$ & $-0,09$ & 0,10 & 0,26 & $-0,28$ \\
\hline Leukocytes Blood & $-0,30$ & $-0,00$ & $-0,14$ & $-0,17$ & $-0,06$ & $-0,04$ & $-0,07$ \\
\hline Monocytes Blood & 0,20 & 0,01 & $-0,13$ & $-0,45$ & $-0,30$ & 0,07 & $-0,35$ \\
\hline Pan-Lymphocytes Blood & $-0,10$ & 0,18 & $-0,10$ & 0,30 & $-0,01$ & 0,03 & 0,07 \\
\hline Stub Neutrophils Blood & $-0,03$ & $-0,02$ & 0,06 & $-0,23$ & 0,07 & 0,00 & $-0,14$ \\
\hline Eosinophiles Blood & 0,00 & $-0,08$ & 0,04 & $-0,06$ & 0,28 & $-0,01$ & 0,05 \\
\hline Natural Killers Blood & 0,13 & $-0,11$ & $-0,16$ & $-0,41$ & $-0,30$ & $-0,01$ & $-0,23$ \\
\hline T helper Lymphocytes Blood & $-0,10$ & 0,31 & $-0,09$ & 0,06 & 0,02 & 0,24 & $-0,03$ \\
\hline T cytolytic Lymphocytes Blood & 0,01 & $-0,12$ & 0,07 & 0,10 & 0,12 & $-0,13$ & $-0,05$ \\
\hline B Lymphocytes Blood & $-0,19$ & 0,06 & $-0,09$ & 0,17 & 0,14 & 0,04 & $-0,04$ \\
\hline
\end{tabular}


Table 2. Regression Summary for Creatinineemia

$\mathrm{R}=0,567 ; \mathrm{R}^{2}=0,322 ;$ Adjusted $\mathrm{R}^{2}=0,272 ; \mathrm{F}_{(4,6)}=6,5 ; \mathrm{p}=0,0002$

\begin{tabular}{|l|l|l|l|l|l|l|l|}
\hline \multicolumn{2}{|l|}{} & Beta & $\begin{array}{l}\text { St. Err. } \\
\text { of Beta }\end{array}$ & B & $\begin{array}{l}\text { St. Err. } \\
\text { of B }\end{array}$ & t $_{(55)}$ & $\begin{array}{l}\text { p- } \\
\text { level }\end{array}$ \\
\hline Variables & $\mathrm{r}$ & & Intercpt & 0,033 & 0,049 & 0,67 & 0,505 \\
\hline Th Lymphocytes Blood, \% & $\mathbf{0 , 3 1}$ & 0,370 & 0,113 & 0,0033 & 0,0010 & 3,27 & 0,002 \\
\hline Spleen Mass Index, g/100g & $\mathbf{0 , 3 0}$ & 0,304 & 0,111 & 0,154 & 0,056 & 2,74 & 0,008 \\
\hline Reticulocytes Thymus, \% & $-0,24$ & $-0,265$ & 0,115 & $-0,0074$ & 0,0032 & $-2,30$ & 0,025 \\
\hline Entropy Leukocytogram & $\mathbf{- 0 , 2 6}$ & $-0,212$ & 0,113 & $-0,115$ & 0,061 & $-1,88$ & 0,065 \\
\hline
\end{tabular}

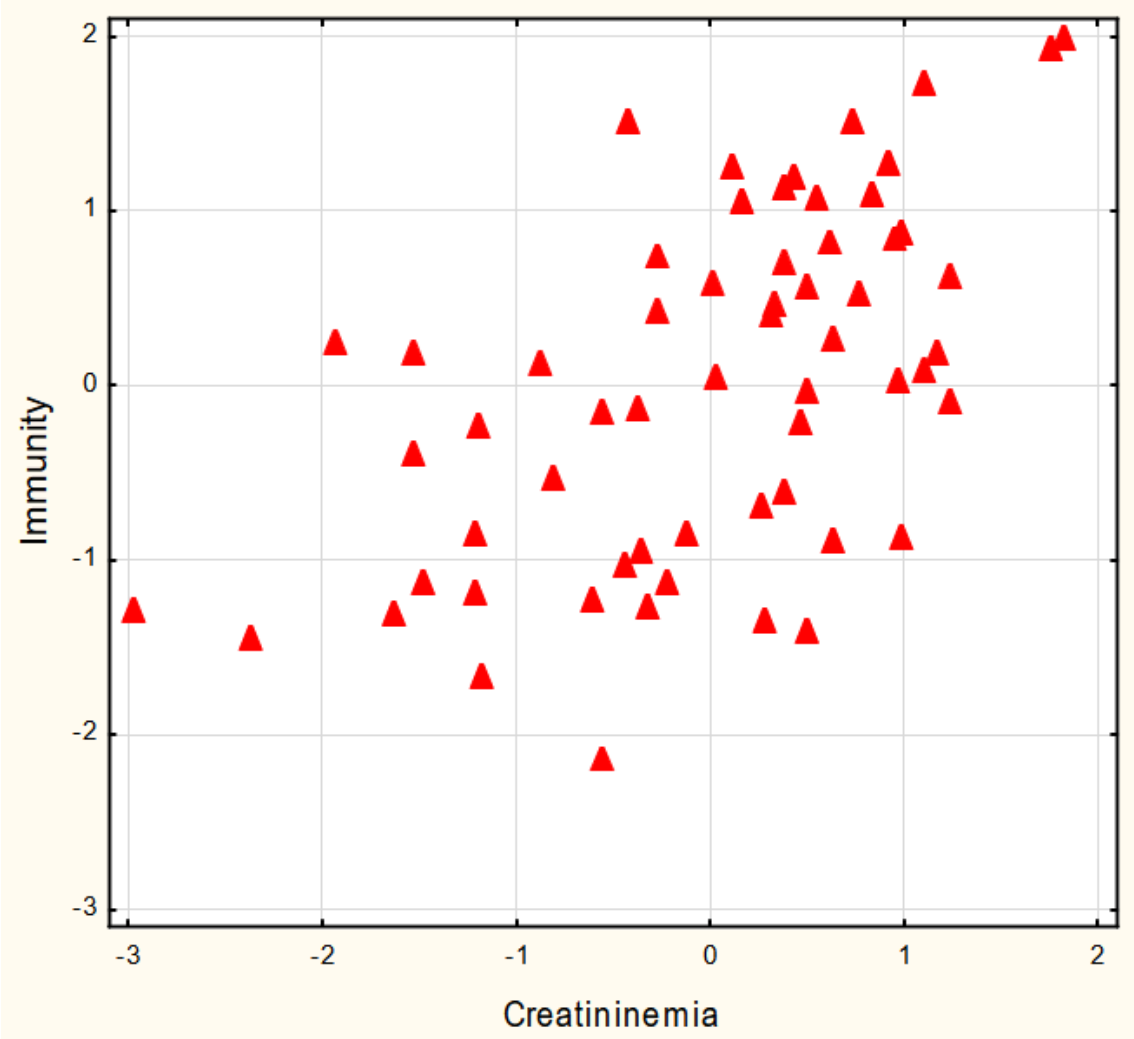

$\mathrm{R}=0,567 ; \mathbf{R}^{2}=0,322 ; \chi_{(4)}^{2}=21,7 ; p=0,0002 ; \Lambda$ Prime $=0,678$

Fig. 1. Scatterplot of canonical correlation between Creatinineemia (X-line) and the Immunity (Y-line) in female rats

Creatinineuria is associated with another immune constellation. It upregulates the mass of the spleen and the content of fibroblasts in the splenocytogram, as well as the content of macrophages in the thymus, while downregulates the content in the thymus lymphoblasts, the level of leukocytes in the blood and the intensity of phagocytosis of microbes by blood neutrophils. The immunomodulatory ability of creatinineuria is 29,5\% (Table 3 and Fig. 2). 
Table 3. Regression Summary for Creatinineuria

$\mathrm{R}=0,606 ; \mathrm{R}^{2}=0,367 ;$ Adjusted $\mathrm{R}^{2}=0,295 ; \mathrm{F}_{(6,5)}=5,1 ; \mathrm{p}=0,0003$

\begin{tabular}{|l|l|l|l|l|l|l|l|}
\hline \multicolumn{2}{|l|}{} & Beta & $\begin{array}{l}\text { St. Err. } \\
\text { of Beta }\end{array}$ & B & $\begin{array}{l}\text { St. Err. } \\
\text { of B }\end{array}$ & $\mathrm{t}_{(53)}$ & $\begin{array}{l}\text { p- } \\
\text { level }\end{array}$ \\
\hline Variables & $\mathrm{r}$ & & Intercpt & 9,853 & 7,216 & 1,37 & 0,178 \\
\hline Fibroblastes Spleen, \% & $\mathbf{0 , 4 0}$ & 0,307 & 0,115 & 0,873 & 0,326 & 2,68 & 0,010 \\
\hline Spleen Mass Index, g/100g & $\mathbf{0 , 2 5}$ & 0,200 & 0,118 & 14,56 & 8,578 & 1,70 & 0,096 \\
\hline Macrophages Thymus, \% & 0,24 & 0,200 & 0,122 & 0,859 & 0,521 & 1,65 & 0,105 \\
\hline Microbial Count Neutrophils & $-0,23$ & $-0,161$ & 0,112 & $-0,578$ & 0,401 & $-1,44$ & 0,156 \\
\hline Leukocytes Blood, 10/L & $\mathbf{- 0 , 3 0}$ & $-0,215$ & 0,116 & $-0,227$ & 0,123 & $-1,86$ & 0,069 \\
\hline Lymphoblastes Thymus, \% & $\mathbf{- 0 , 3 0}$ & $-0,144$ & 0,118 & $-0,705$ & 0,576 & $-1,22$ & 0,226 \\
\hline
\end{tabular}

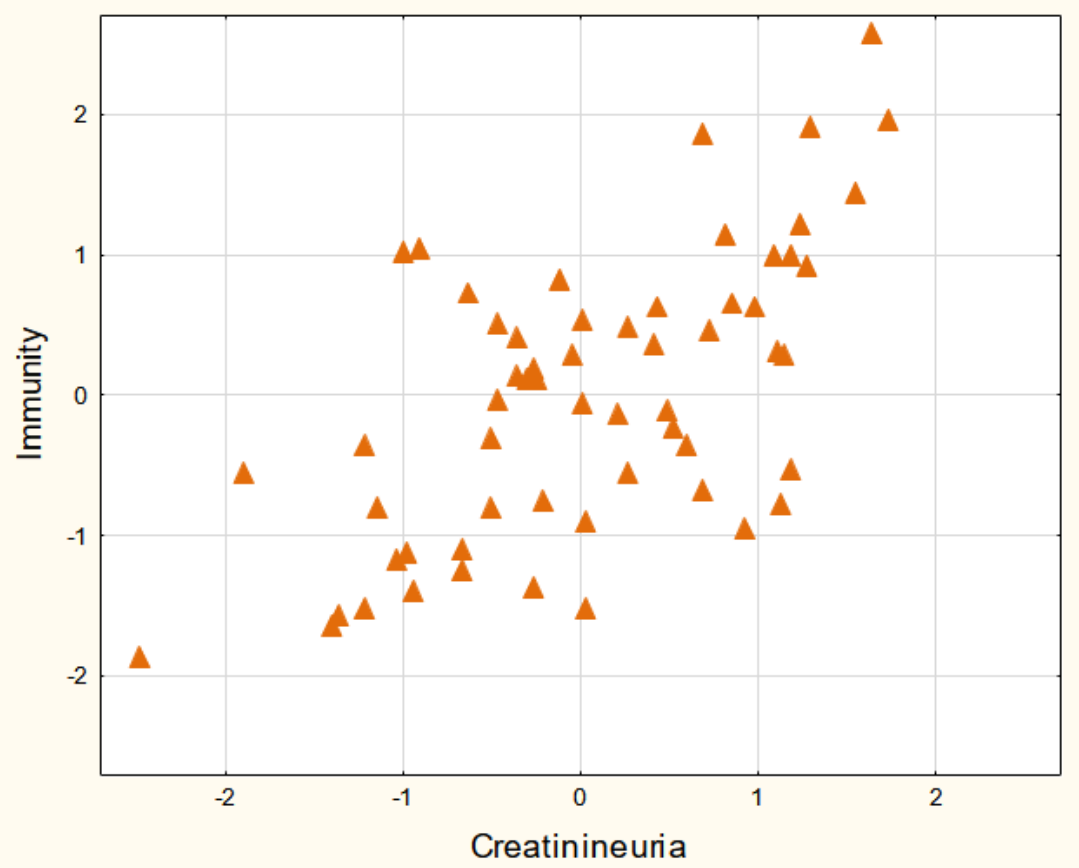

$\mathrm{R}=0,606 ; \mathrm{R}^{2}=0,367 ; \chi_{(6)}^{2}=25,2 ; \mathrm{p}=0,0003 ; \Lambda$ Prime $=0,633$

Fig. 2. Scatterplot of canonical correlation between Creatinineuria (X-line) and the Immunity (Y-line) in female rats

The correlation coefficients between plasma urea and immune parameters are on the verge of significance. As a result, the degree of their determination is only $18,1 \%$, but statistically significant (Table 4 and Fig. 3).

Table 4. Regression Summary for Urea Plasma

$\mathrm{R}=0,500 ; \mathrm{R}^{2}=0,250 ;$ Adjusted $\mathrm{R}^{2}=0,181 ; \mathrm{F}_{(5,5)}=3,6 ; \mathrm{p}=0,007$

\begin{tabular}{|l|l|l|l|l|l|l|l|}
\hline \multicolumn{2}{|l|}{} & Beta & $\begin{array}{l}\text { St. Err. } \\
\text { of Beta }\end{array}$ & B & $\begin{array}{l}\text { St. Err. } \\
\text { of B }\end{array}$ & $\mathrm{t}_{(54)}$ & $\begin{array}{l}\text { p- } \\
\text { level }\end{array}$ \\
\hline Variables & $\mathrm{r}$ & & Intercpt & $-3,254$ & 4,339 & $-0,75$ & 0,457 \\
\hline Endotheliocytes Thymus, \% & $\mathbf{0 , 2 7}$ & 0,223 & 0,124 & 0,733 & 0,409 & 1,79 & 0,079 \\
\hline Hassal's corpuscles Thymus, \% & $\mathbf{0 , 2 6}$ & 0,207 & 0,119 & 1,432 & 0,823 & 1,74 & 0,088 \\
\hline Spleen Mass Index, g/100g & 0,24 & 0,173 & 0,121 & 8,007 & 5,607 & 1,43 & 0,159 \\
\hline Th Lymphocytes Blood, \% & 0,24 & 0,249 & 0,121 & 0,207 & 0,101 & 2,05 & 0,045 \\
\hline Phagocytic Index Monocytes, \% & $-0,23$ & $-0,158$ & 0,120 & $-0,573$ & 0,437 & $-1,31$ & 0,196 \\
\hline
\end{tabular}


Instead, urea excretion bonds are stronger and reflect its enhancing effect on the content of lymphoblasts in the spleen as well as lymphocytes and macrophages in the thymus. The measure of positive determination is $34,7 \%$ (Table 5 and Fig. 4).

Table 5. Regression Summary for Urea Excretion

$\mathrm{R}=0,617 ; \mathrm{R}^{2}=0,381 ;$ Adjusted $\mathrm{R}^{2}=0,347 ; \mathrm{F}_{(3,6)}=11,5 ; \mathrm{p}=10^{-5}$

\begin{tabular}{|l|l|l|l|l|l|l|l|}
\hline \multicolumn{2}{|l|}{} & Beta & $\begin{array}{l}\text { St. Err. } \\
\text { of Beta }\end{array}$ & B & $\begin{array}{l}\text { St. Err. } \\
\text { of B }\end{array}$ & $\mathrm{t}_{(56)}$ & $\begin{array}{l}\text { p- } \\
\text { level }\end{array}$ \\
\hline Variables & $\mathrm{r}$ & & Intercpt & -2137 & 565,5 & $-3,78$ & 0,0004 \\
\hline Lymphoblastes Spleen, \% & $\mathbf{0 , 4 0}$ & 0,244 & 0,112 & 32,53 & 14,95 & 2,18 & 0,0338 \\
\hline Lymphocytes Thymus, \% & $\mathbf{0 , 3 4}$ & 0,430 & 0,119 & 29,13 & 8,08 & 3,61 & 0,0007 \\
\hline Macrophages Thymus, \% & $\mathbf{0 , 3 1}$ & 0,441 & 0,115 & 68,24 & 17,84 & 3,82 & 0,0003 \\
\hline
\end{tabular}

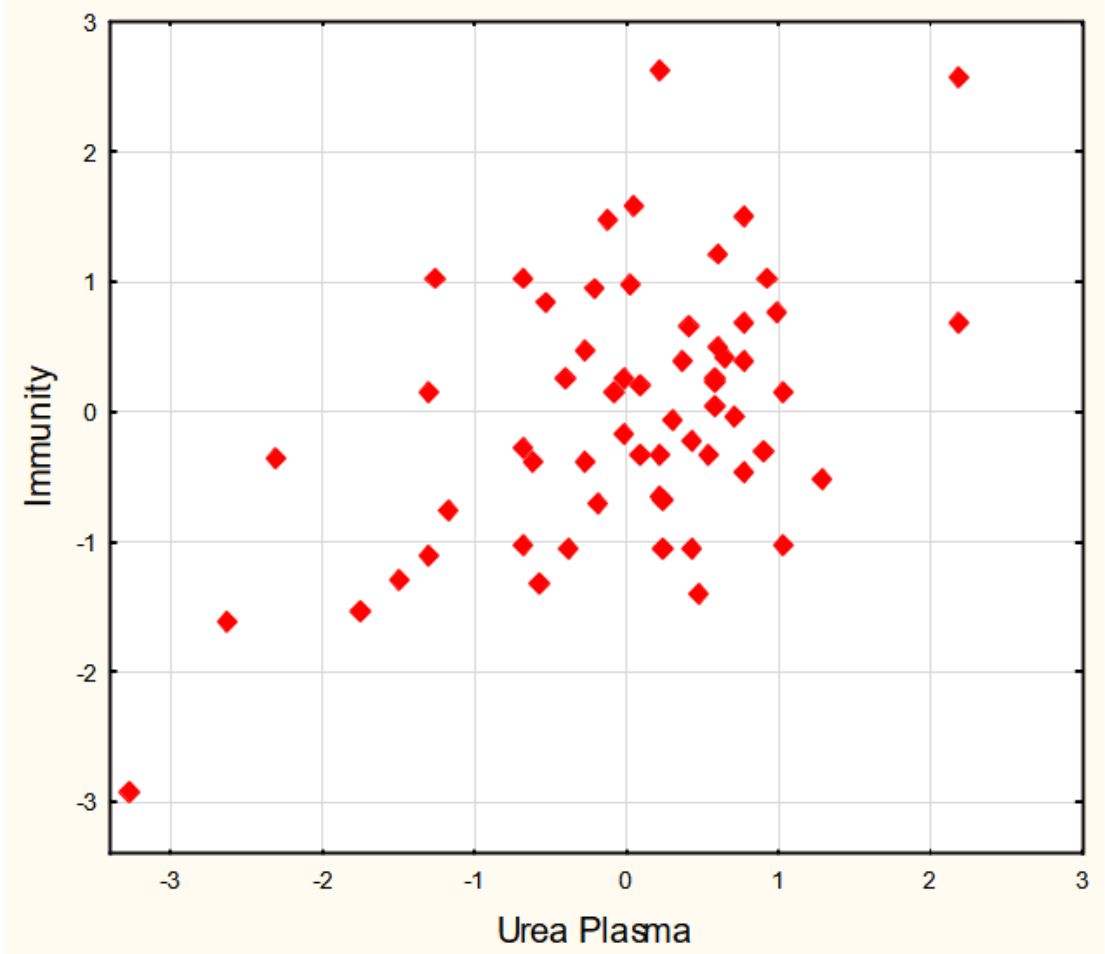

$\mathrm{R}=0,500 ; \mathrm{R}^{2}=0,250 ; \chi_{(5)}^{2}=16,0 ; \mathbf{p}=0,007 ; \Lambda$ Prime $=0,750$

Fig. 3. Scatterplot of canonical correlation between Urea Plasma (X-line) and the Immunity (Y-line) in female rats 


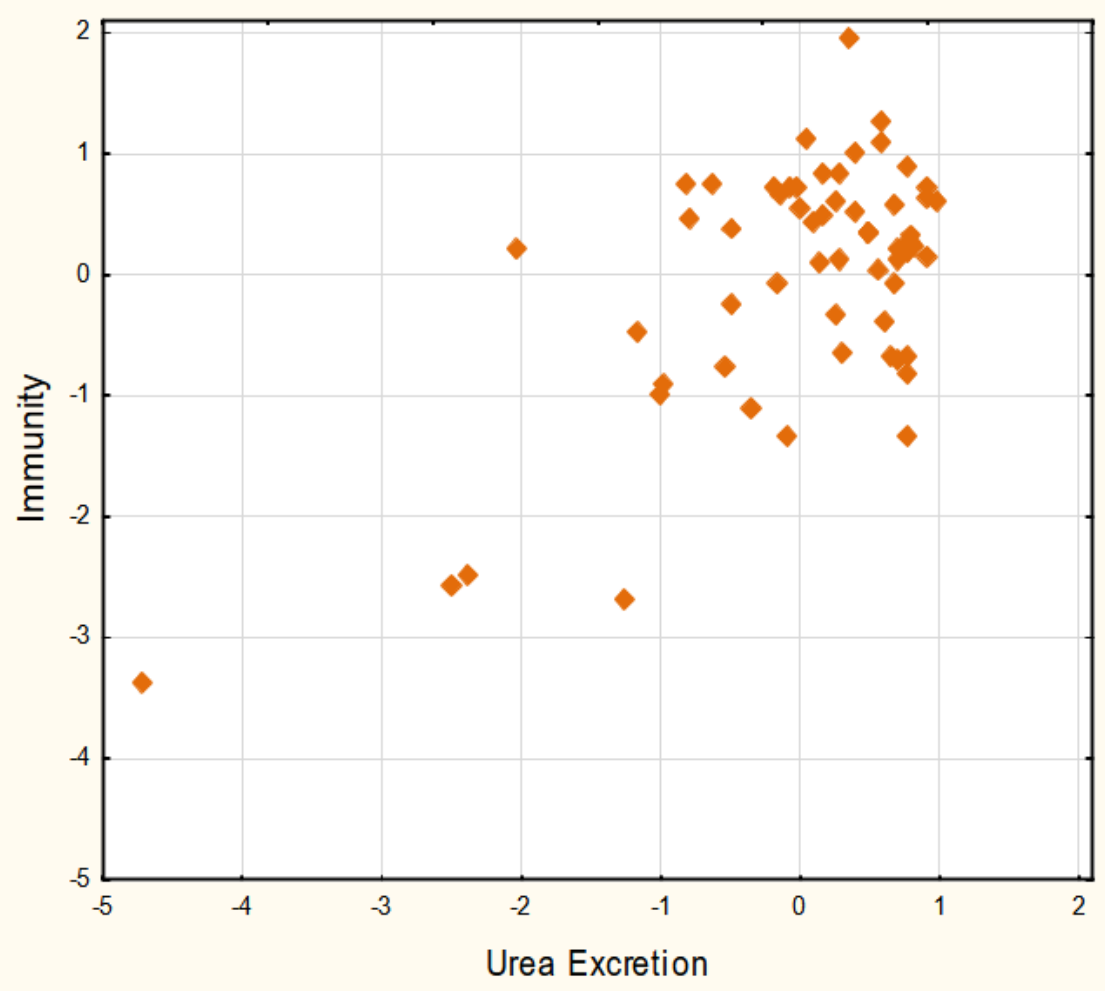

$\mathrm{R}=0,617 ; \mathrm{R}^{2}=0,381 ; \chi_{(3)}^{2}=27,1 ; \mathrm{p}=10^{-5} ; \Lambda$ Prime $=0,619$

Fig. 4. Scatterplot of canonical correlation between Urea Excretion (X-line) and the Immunity (Y-line) in female rats

The immunotropic effect of uricemia is exclusively suppressive and is manifested in relation to the level in the blood of monocytes and natural killers and Hassal's corpuscles in the thymus, as well as the entropy of the blood leukocytogram. The measure of negative determination is $27,1 \%$ (Table 6 and Fig. 5).

Table 6. Regression Summary for Uricemia

$\mathrm{R}=0,566 ; \mathrm{R}^{2}=0,320 ;$ Adjusted $\mathrm{R}^{2}=0,271 ; \mathrm{F}_{(4,6)}=6,5 ; \mathrm{p}=0,0002$

\begin{tabular}{|l|l|l|l|l|l|l|l|}
\hline \multicolumn{2}{|l|}{} & Beta & $\begin{array}{l}\text { St. Err. } \\
\text { of Beta }\end{array}$ & B & $\begin{array}{l}\text { St. Err. } \\
\text { of B }\end{array}$ & t $_{(55)}$ & $\begin{array}{l}\text { p- } \\
\text { level }\end{array}$ \\
\hline Variables & $\mathrm{r}$ & & Intercpt & -1216 & 843 & $-1,44$ & 0,155 \\
\hline Monocytes Blood, \% & $\mathbf{- 0 , 3 5}$ & $-0,933$ & 0,271 & $-171,2$ & 49,7 & $-3,44$ & 0,001 \\
\hline Hassal's corpuscles Thymus, \% & $\mathbf{- 0 , 2 8}$ & $-0,250$ & 0,113 & $-244,8$ & 110,0 & $-2,23$ & 0,030 \\
\hline Entropy Leukocytogram & $-0,24$ & 0,292 & 0,113 & 2044 & 788 & 2,59 & 0,012 \\
\hline Natural Killers Blood, \% & $-0,23$ & 0,633 & 0,271 & 128,5 & 55,0 & 2,34 & 0,023 \\
\hline
\end{tabular}




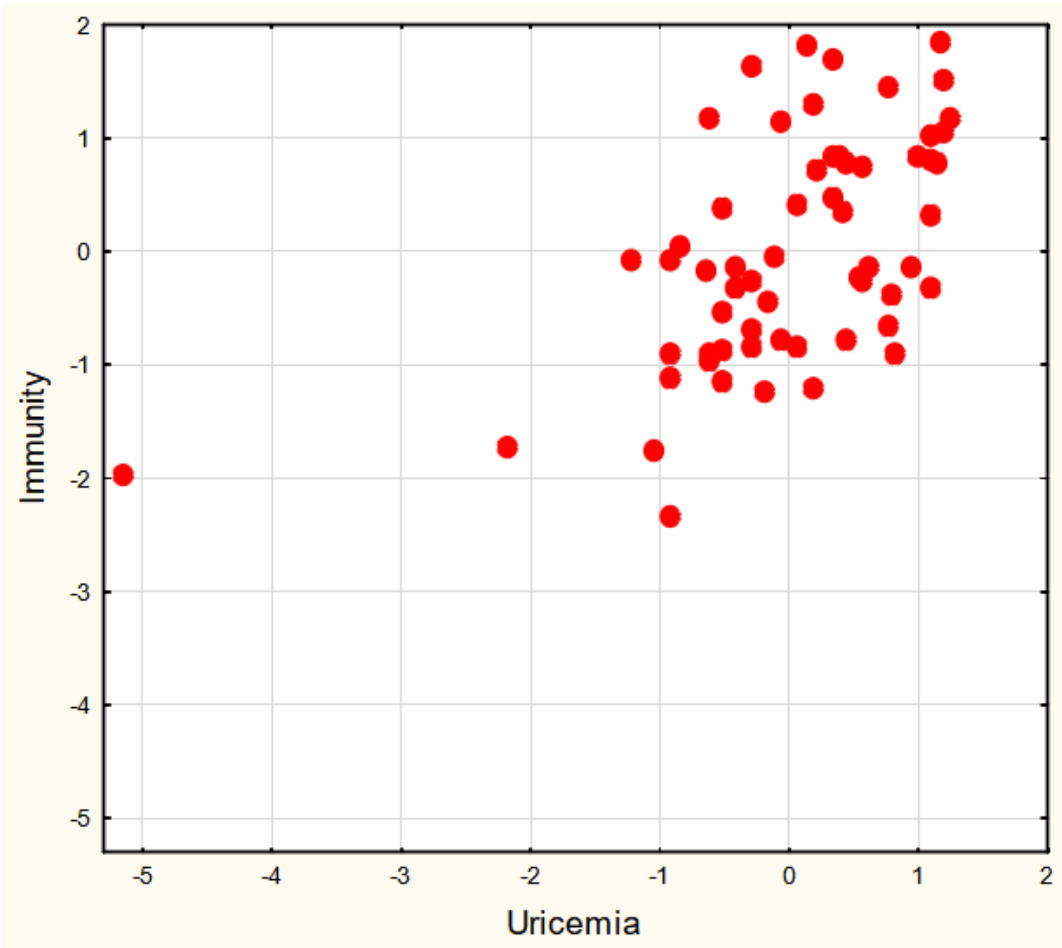

$\mathrm{R}=0,566 ; \mathrm{R}^{2}=0,320 ; \chi_{(4)}^{2}=21,6 ; p=0,0002 ; \Lambda$ Prime $=0,680$

Fig. 5. Scatterplot of canonical correlation between Uricemia ( $\mathrm{X}$-line) and the Immunity (Y-line) in female rats

The immunotropic effects of uricosuria are ambiguous. It upregulates the intensity (Fig. 6) and activity of phagocytosis, while downregulates blood levels of eosinophils and rodshaped neutrophils, as well as reticulocytes in the thymus. The degree of immunomodulation is $35,1 \%$ (Table 7 and Fig. 7 ).

Bilirubin upregulates the content in the splenocytogram of lymphoblasts and its entropy, as well as the level of eosinophils in the blood and the intensity of phagocytosis, while downregulates the content in the splenocytogram of microphages. The degree of immunomodulation is $28,6 \%$ (Table 8 and Fig. 8 ). 


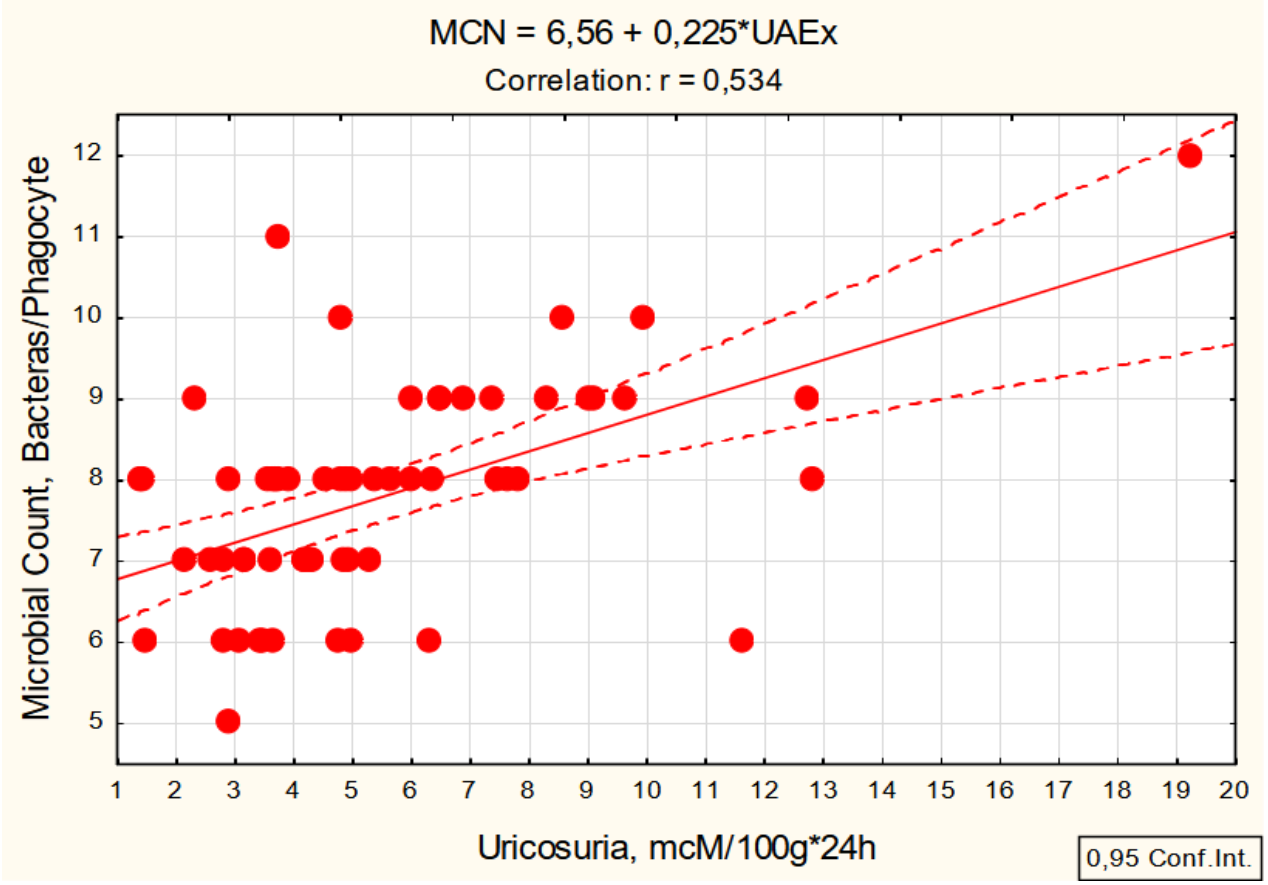

Fig. 6. Scatterplot of correlation between Uricosuria (X-line) and Microbial Count of Blood Neutrophils (Y-line) in female rats

Table 7. Regression Summary for Uricosuria

$\mathrm{R}=0,637 ; \mathrm{R}^{2}=0,406 ;$ Adjusted $\mathrm{R}^{2}=0,351 ; \mathrm{F}_{(5,5)}=7,4 ; \mathrm{p}<10^{-4}$

\begin{tabular}{|l|l|l|l|l|l|l|l|}
\hline \multicolumn{2}{|l|}{} & Beta & $\begin{array}{l}\text { St. Err. } \\
\text { of Beta }\end{array}$ & B & $\begin{array}{l}\text { St. Err. } \\
\text { of B }\end{array}$ & $\mathrm{t}_{(54)}$ & $\begin{array}{l}\text { p- } \\
\text { level }\end{array}$ \\
\hline Variables & $\mathrm{r}$ & & Intercpt & 10,09 & 7,64 & 1,32 & 0,192 \\
\hline Microbial Count Neutrophils & $\mathbf{0 , 5 3}$ & 0,539 & 0,140 & 1,278 & 0,331 & 3,86 & 0,0003 \\
\hline Phagocytic Ind Neutrophils, \% & $\mathbf{0 , 3 0}$ & $-0,163$ & 0,140 & $-0,139$ & 0,119 & $-1,16$ & 0,251 \\
\hline Stub Neutrophils Blood, \% & $-0,23$ & $-0,204$ & 0,111 & $-0,572$ & 0,311 & $-1,84$ & 0,071 \\
\hline Reticulocytes Thymus, \% & $\mathbf{- 0 , 2 6}$ & $-0,128$ & 0,113 & $-0,343$ & 0,302 & $-1,14$ & 0,261 \\
\hline Eosinophiles Spleen, \% & $\mathbf{- 0 , 3 5}$ & $-0,247$ & 0,110 & $-0,950$ & 0,422 & $-2,25$ & 0,029 \\
\hline
\end{tabular}

Table 8. Regression Summary for Bilirubinemia

$\mathrm{R}=0,589 ; \mathrm{R}^{2}=0,346 ;$ Adjusted $\mathrm{R}^{2}=0,286 ; \mathrm{F}_{(5,5)}=5,7 ; \mathrm{p}=0,0003$

\begin{tabular}{|l|l|l|l|l|l|l|l|}
\hline \multicolumn{2}{|l}{} & Beta & $\begin{array}{l}\text { St. Err. } \\
\text { of Beta }\end{array}$ & B & $\begin{array}{l}\text { St. Err. } \\
\text { of B }\end{array}$ & t $_{(54)}$ & $\begin{array}{l}\text { p- } \\
\text { level }\end{array}$ \\
\hline Variables & r & & Intercpt & $-8,139$ & 8,457 & $-0,96$ & 0,340 \\
\hline Lymphoblastes Spleen, \% & $\mathbf{0 , 4 2}$ & 0,329 & 0,119 & 0,540 & 0,195 & 2,76 & 0,008 \\
\hline Eosinophiles Blood, \% & $\mathbf{0 , 2 8}$ & 0,253 & 0,111 & 0,278 & 0,122 & 2,28 & 0,027 \\
\hline Microbial Count Neutrophils & $\mathbf{0 , 2 8}$ & 0,203 & 0,113 & 0,323 & 0,180 & 1,79 & 0,079 \\
\hline Entropy Splenocytogram & $\mathbf{0 , 2 7}$ & 0,133 & 0,116 & 12,82 & 11,18 & 1,15 & 0,257 \\
\hline Microphages Spleen, \% & $-0,22$ & $-0,196$ & 0,110 & $-0,206$ & 0,116 & $-1,78$ & 0,081 \\
\hline
\end{tabular}




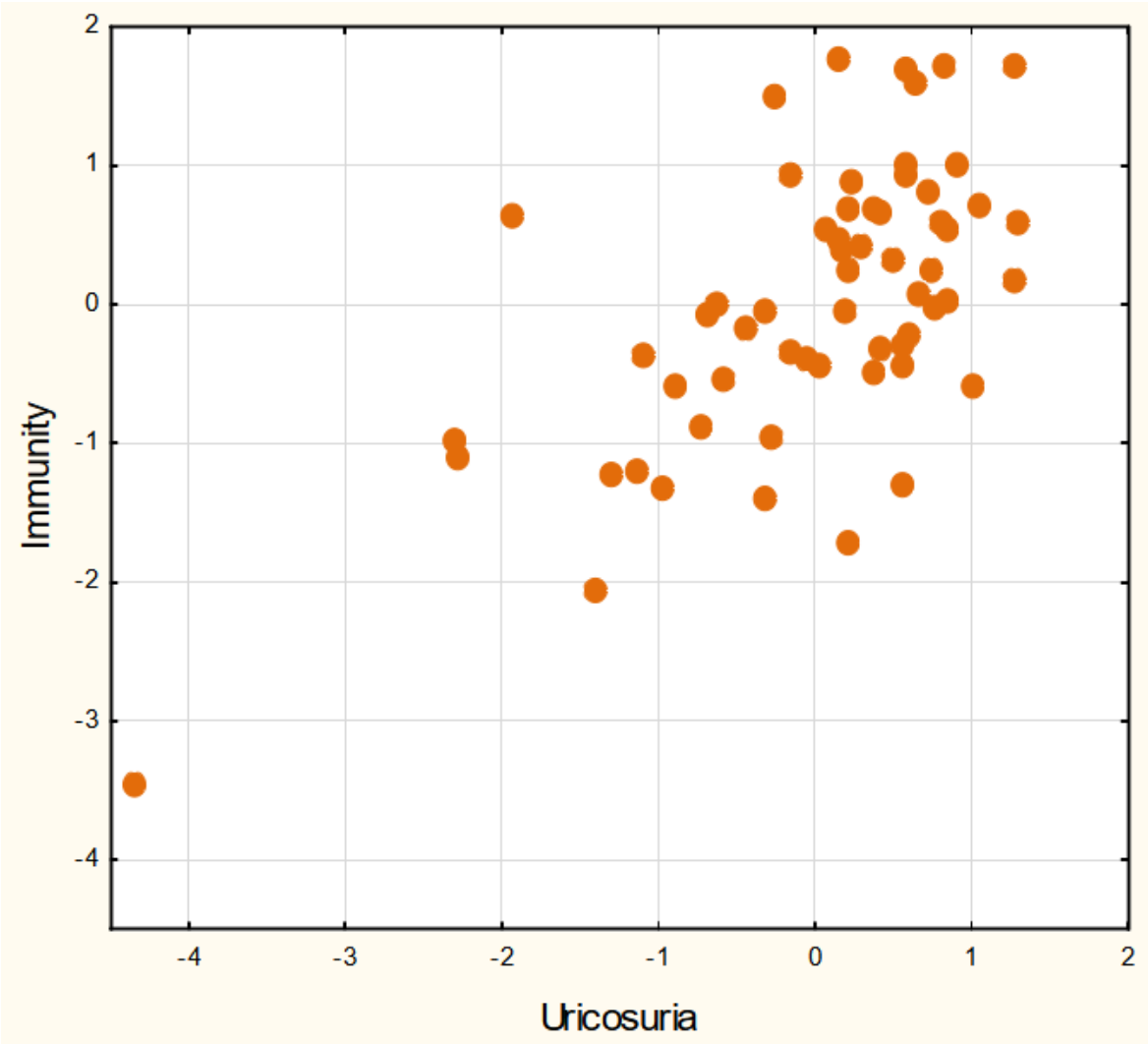

$\mathrm{R}=0,637 ; \mathrm{R}^{2}=0,406 ; \chi_{(5)}^{2}=28,9 ; \mathrm{p}<10^{-4} ; \Lambda$ Prime $=0,594$

Fig. 7. Scatterplot of canonical correlation between Uricosuria (X-line) and the Immunity (Y-line) in female rats

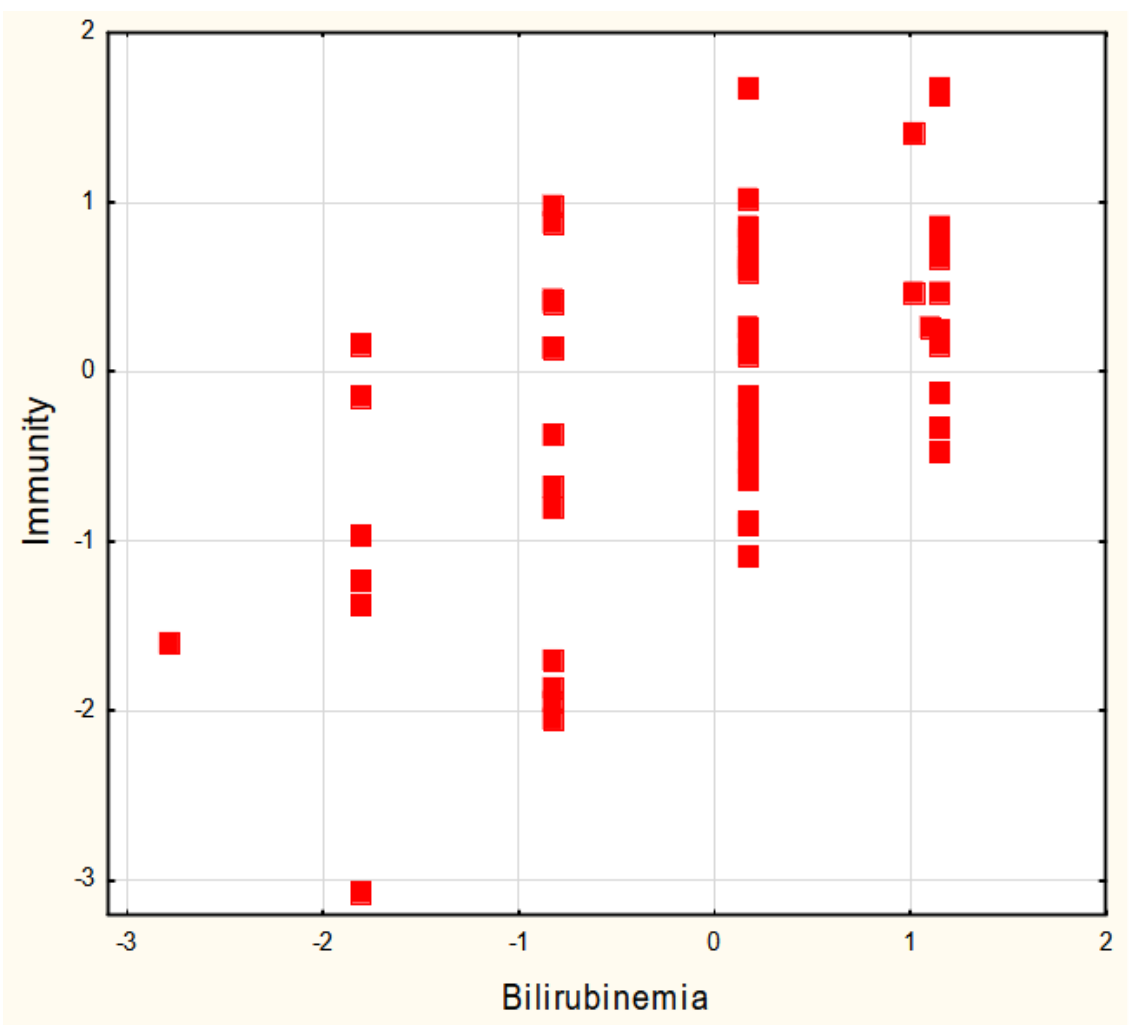

$\mathrm{R}=0,589 ; \mathrm{R}^{2}=0,346 ; \chi_{(5)}^{2}=23,6 ; p=0,0003 ; \Lambda$ Prime $=0,654$

Fig. 8. Scatterplot of canonical correlation between Bilirubinemia (X-line) and the Immunity (Y-line) in female rats 
The combined effect of uricosuria and bilirubinemia on the intensity of neutrophil phagocytosis is only slightly greater than the effect of uricosuria itself (Fig. 9).

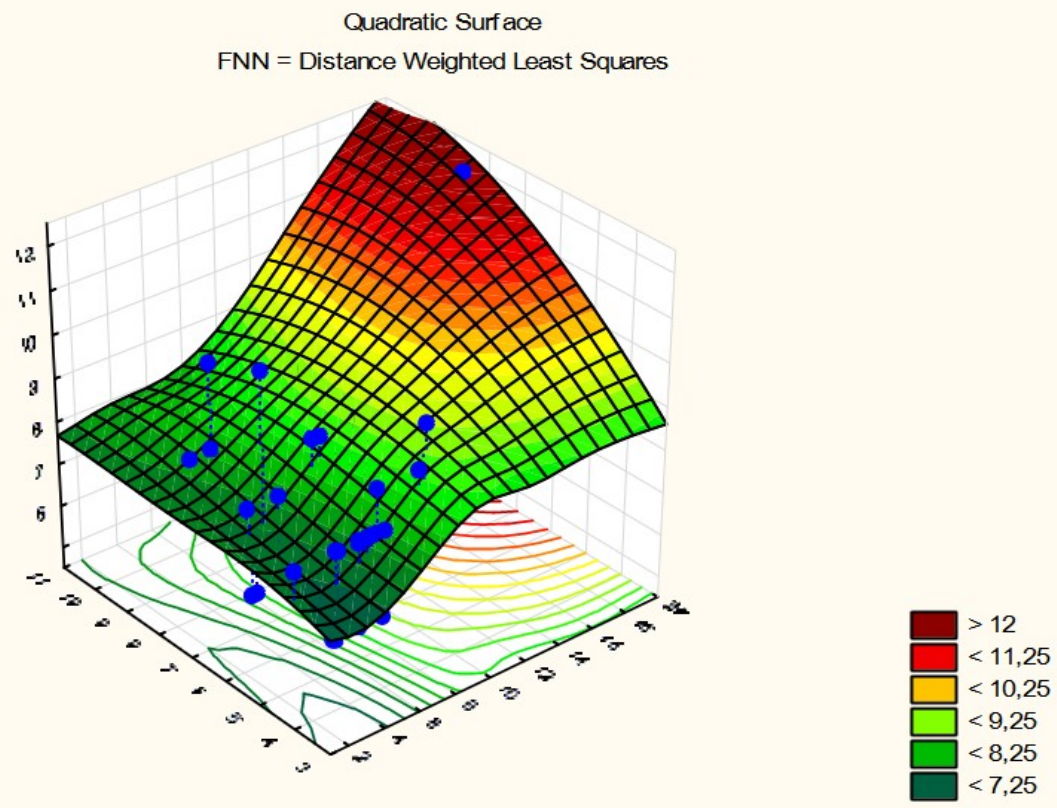

$\mathrm{Z}=6,00+0,213 \cdot \mathrm{X}+0,136 \cdot \mathrm{Y} ; \mathrm{R}=0,575 ; \mathrm{R}^{2}=0,331 ;$ Adjusted $\mathrm{R}^{2}=0,307 ; \mathrm{F}_{(2,6)}=14 ; \mathrm{p}<10^{-5}$

Fig. 9. The combined effect of uricosuria $(\mu \mathrm{M} / 100 \mathrm{~g} \cdot 24 \mathrm{~h} ; \mathrm{X}$-line) and bilirubinemia $(\mu \mathrm{M} / \mathrm{L} ; \mathrm{Y}$-line) on the intensity of neutrophil phagocytosis (Bacteras/Phagocyte; Z-line)

Because nitrogenous metabolites and immunocytes do not interact alone, but as biochemical and immune complexes, the method of choice for evaluating such interactions is canonical correlation (Table 9). 
Table 9. Factor load on canonical roots of nitric metabolites and immunity parameters

\begin{tabular}{|c|c|c|}
\hline Left set & Root 1 & Root 2 \\
\hline Uricosuria & ,686 &, 070 \\
\hline Bilirubinemia & ,438 & ,206 \\
\hline Uricemia & ,392 &,- 011 \\
\hline Urea Excretion & ,264 &, 897 \\
\hline Creatininuria &,- 242 &, 511 \\
\hline Urea Plasma &,- 089 & ,394 \\
\hline Creatininemia &, 036 & ,348 \\
\hline Right set & Root 1 & Root 2 \\
\hline Microbial Count Neutrophils &, 803 &,- 113 \\
\hline Lymphoblastes Spleen, \% &, 479 &, 391 \\
\hline Phagocytic Index Neutrophils, \% &, 441 & , 143 \\
\hline Lymphocytes Thymus, \% &, 428 & ,347 \\
\hline Lymphoblastes Thymus, \% &, 272 &,- 085 \\
\hline Endotheliocytes Thymus, \% & ,091 & ,022 \\
\hline Th Lymphocytes Blood, \% &, 067 &,- 012 \\
\hline Eosinophiles Blood, \% &, 067 &, 015 \\
\hline Monocytes Blood, \% &,- 745 &, 060 \\
\hline Natural Killers Blood, \% &,- 644 &,- 047 \\
\hline Eosinophiles Spleen, \% &,- 468 &,- 103 \\
\hline Reticulocytes Thymus, \% &,- 345 &,- 073 \\
\hline Hassal's corpuscles Thymus, \% &,- 201 &,- 063 \\
\hline Spleen Mass Index, g/100g &,- 250 & ,261 \\
\hline Entropy Splenocytogram &,- 053 & ,246 \\
\hline Macrophages Thymus, \% &, 082 & ,305 \\
\hline Fibroblastes Spleen, \% &,- 132 & ,199 \\
\hline Stub Neutrophils Blood, $\%$ &,- 139 & ,147 \\
\hline Entropy Leukocytogram &,- 026 &,- 265 \\
\hline Microphages Spleen, \% &,- 092 &,- 203 \\
\hline Phagocytic Index Monocytes, \% &,- 114 &,- 141 \\
\hline Leukocytes Blood, $10^{9} / \mathrm{L}$ &, 020 &,- 113 \\
\hline
\end{tabular}

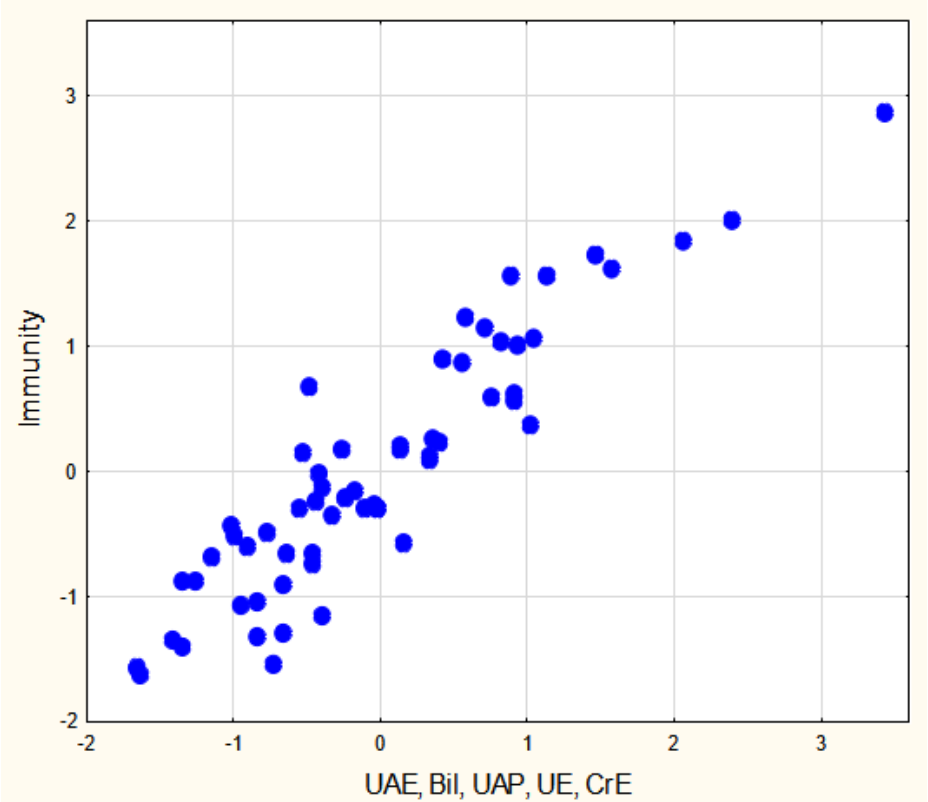

$R=0,921 ; R^{2}=0,848 ; \chi_{(154)}^{2}=282 ; p=10^{-6} ; \Lambda$ Prime $=0,0032$

Fig. 10. Scatterplot of canonical correlation between the nitric metabolites (X-line) and the Immunity (Y-line) in female rats. The first pair of roots 


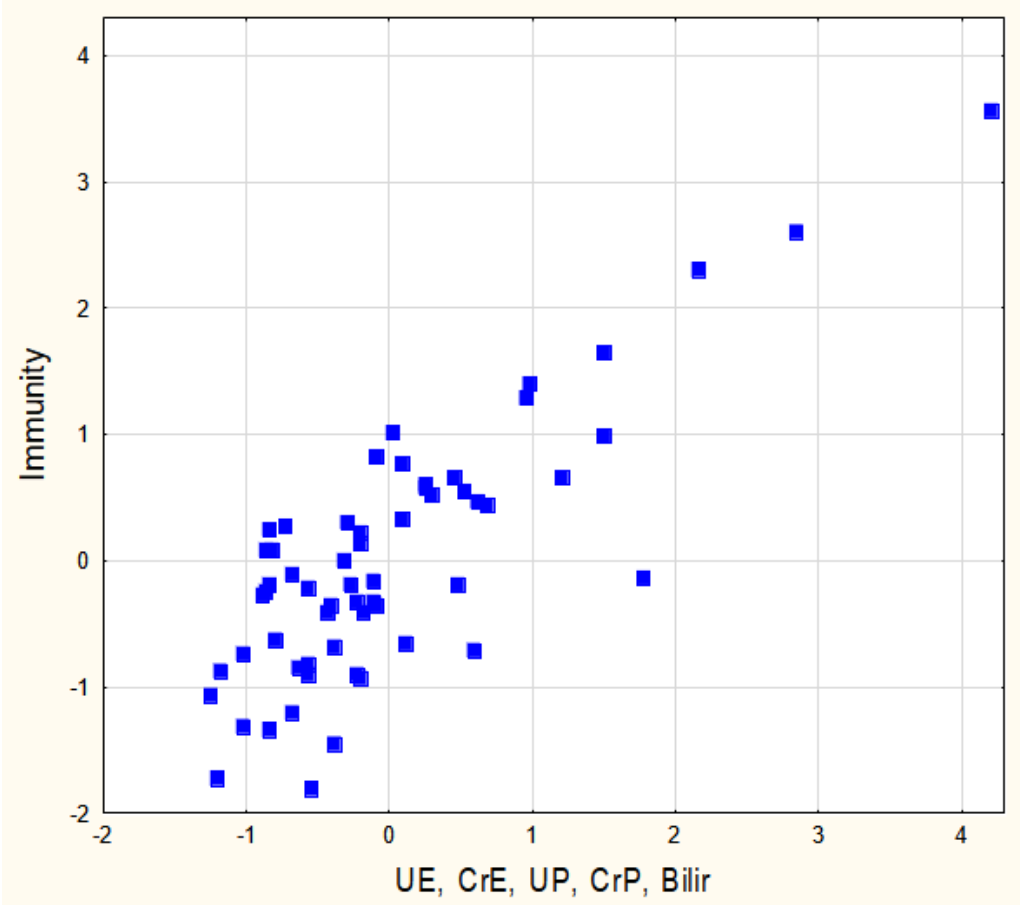

$R=0,816 ; R^{2}=0,665 ; \chi_{(126)}^{2}=169 ; p=0,006 ; \Lambda$ Prime $=0,021$

Fig. 11. Scatterplot of canonical correlation between the nitric metabolites ( $\mathrm{X}$-line) and the Immunity (Y-line) in female rats. The second pair of roots

As a result of canonical analysis, two pairs of canonical roots were formed. Nitrogen root of the first pair, judging by the factor loads, represents mainly uric acid and bilirubin. The immune root of the first pair contains information about the parameters of the thymus, spleen and blood, which are subject to stimulating or suppressive effects of uric acid and bilirubin. The immunomodulatory effect of these nitrogenous metabolites, judging by the coefficient of determination, is very significant (Fig. 10).

The nitrogen root of the second pair represents mainly urea and creatinine. Their immunomodulatory effect is directed to another constellation of immune parameters and is much weaker (Fig. 11). However, there is approximately the same effect of both pairs of metabolites on the content of lymphoblasts in the spleen and lymphocytes in the thymus, while different effects on the relative mass of the spleen.

\section{DISCUSSION}

Assuming that the correlations reflect causal relationships, uric acid can be found to have significant immunomodulatory activity, upregulating the activity and intensity of phagocytosis Staph. aureus by blood neutrophils, instead downregulating the content of rodshaped neutrophils, monocytes and natural killers in the blood. Our findings are consistent with data from Martínez-Reyes CP et al [27], which showed in vitro that incubation of human macrophages for 12 hours in the presence of increasing concentrations of uric acid $(0,23 ; 0,45$ and $0,9 \mathrm{mM} / \mathrm{L}$, ie comparable to its level in plasma) dose-dependently increased their phagocytic activity, which was defined as the percentage of macrophages containing labeled Escherichia coli. This was accompanied by increased expression of TL4-receptors and increased production of TNF- $\alpha$. A possible mechanism by which uric acid exerts a proinflammatory effect on human macrophages affects the anionic transporter of urate URAT1 in a dose-dependent manner. URAT1, in turn, may enhance NF- $\mathrm{B}$ activation and lead to the production of proinflammatory cytokines in ways yet to be elucidated. In the same 
experiment, uric acid simultaneously inhibited the expression of CX3CR1- and CCR2receptors, which are involved in inhibiting the recruitment of monocytes from the blood to sites of inflammation, where these cells differentiate into macrophages. This agrees well with our other fact about the downregulation by uric acid levels in the blood of monocytes, apparently due to the activation of their translocation into tissues.

The downregulation of natural killer blood level found in our study is also consistent with the data of Gao L et al [13], that in human asymptomatic hyperuricemia is accompanied by low levels of NK cells in the blood. However, Carvalho LAC et al [7] during incubation with uric acid of neutrophil-like cells (HL-60) stated inhibition of their killing activity against Pseudomonas aeruginosa as well as decreasing the release of the inflammatory cytokines.

It is known that innate phagocytes, including dendritic cells, macrophages and neutrophils, can use TL-receptors to recognize uric acid, more precisely sodium urate crystals, as one of the pro-inflammatory endogenous signals secreted by dead or damaged cells. These molecular structures associated with damage can trigger a systemic inflammatory response similar to molecular patterns associated with pathogens [14].

In addition to TL-receptors, adenosine receptors may mediate the immunotropic effects of uric acid. Uric acid (2,6,8-trioxipurine) is a structural homolog of adenosine [ $(2 \mathrm{R}, 3 \mathrm{R}, 4 \mathrm{R}, 5 \mathrm{R})$ 2-(6-aminopurine-il)-5-(hydroximethyl) oxolan-3,4-diol)] as well as theophylline (2,6-dioxi1,3-dimethylpurine or 1,3-dimethylxantine) and caffeine (2,6-dioxi-1,3,7-trimethylpurine or 1,3,7-trimethylxantine). It is known that the immunotropic effect of adenosine is realized through its receptors $\left(\mathrm{A}_{1}, \mathrm{~A}_{2 \mathrm{~A}}, \mathrm{~A}_{2 \mathrm{~B}}, \mathrm{~A}_{3}\right)$, which express virtually all populations of immunocytes: T, NK, B lymphocytes, macrophages, neutrophils, dendritic and endothelial cells $[1,22,23,42]$. Methylxanthines are nonselective antagonists of adenosine receptors, mainly $A_{2 A}$ and $A_{1}[8,28,29,30,35]$. The facts obtained in our $[19,20]$ previous human studies on the inversely relationship of uricemia (the level of which is comparable to the concentrations of adenosine and theophylline in immune tests in vitro) with a relative blood content of $\mathrm{CD}^{+} \mathrm{CD}^{+} \mathrm{T}$-helper cells in combination with the presence of directly connection with the content of $\mathrm{CD}^{+} \mathrm{CD}^{+} \mathrm{T}$-cytolytic cells indicate the similarity of the effects of uric acid with those of adenosine, ie activation of $\mathrm{A}_{2 \mathrm{~A}}$ receptors.

The second strongest immunomodulator in this study was bilirubin, which upregulates the intensity of neutrophil phagocytosis, the level of eosinophils in the blood and lymphoblasts in the spleen, as well as the entropy of the splenocytogram, while downregulates the level of macrophage in the spleen.

Phelan D et al [32] demonstrated that the heme degradation products bilirubin and biliverdin are aryl hydrocarbon receptor (AhR) ligands which can regulate the AhR-dependent gene expression pathway. AhR translocates into the nucleus upon binding of various small molecules into the pocket of its single-ligand binding domain. AhR binding to both xenobiotic and endogenous ligands results in highly cell-specific transcriptome changes and in changes in cellular functions [12]. Although the AhR was initially recognized as the receptor mediating the pathologic effects of dioxins and other pollutants [2], the activation of AhR by endogenous and environmental factors has important physiologic effects, including the regulation of the immune response $[9,10,36,43]$. Both adaptive and innate immune cells require AhR signaling at critical checkpoints. AhR signaling is considered a promising drug and preventive target, particularly for cancer, inflammatory, and autoimmune diseases [12].

It is noteworthy that currently known receptors for the implementation of immunotropic effects are the most powerful among our studied - uric acid and bilirubin, while reports of immunocyte expression of receptors for creatinine and urea on the resources of PubMed and PMC we could not find, as well as work on immunotropic effects creatinine and urea.

Since they do occur, we hypothesize the realization of the immunotropic effects of these and previous nitrogenous metabolites through their effect on neurogenic and endocrine 
mechanisms of immunomodulation. Our hypothesis is based on the concepts of functionalmetabolic continuum [16] and neuroendocrine immunomodulation [21,25,34,38-41,44].

Data in support of our hypothesis will be given in subsequent publications.

\section{CONFORMITY TO ETHICAL STANDARDS}

Experiments on animals have been carried out in accordance with the provisions of the Helsinki Declaration of 1975, revised and supplemented in 2002 by the Directives of the National Committees for Ethics in Scientific Research.

The conduct of experiments was approved by the Ethics Committee of the Ukrainian Scientific Research Institute for Medicine of Transport. The modern rules for the maintenance and use of laboratory animals complying with the principles of the European Convention for the Protection of Vertebrate Animals used for scientific experiments and needs are observed (Strasbourg, 1985).

\section{REFERENCES}

1. Apasov S, Chen JF, Smith P, Sitkovsky M. $A_{2 A}$ receptor dependent and $A_{2 A}$ receptor independent effects of extracellular adenosine on murine thymocytes in condicion of adenosine deaminase deficiency. Blood. 2000; 95(12): 3859-3867.

2. Avilla MN, Malecki KMC, Hahn ME, Wilson RH, Bradfield CA. The Ah Receptor: Adaptive Metabolism, Ligand Diversity, and the Xenokine Model. Chem Res Toxicol. 2020; 33(4): 860-879.

3. Bazarnova MA. Cytology investigation of the punctates of the spleen. In: Guide to practical training in clinical laboratory diagnostics [in Russian]. Kyiv. Vyshcha shkola; 1988: 263-264.

4. Belousova OI, Fedotova MI. Comparative data on changes in spleen, thymus and bone marrow lymphocyte counts in the early post-irradiation period over a wide range of doses [in Russian]. Radiobiology-Radiotherapy. 1968; 9(3): 309-313.

5. Bianco C. Population of lymphocytes bearing a membrane receptor for antigen-antibody complex. J Exp Med. 1970; 134(4): 702-720.

6. Bilas VR, Popovych IL. Role of microflora and organic substances of water Naftussya in its modulating influence on neuroendocrine-immune complex and metabolism [in Ukrainian]. Medical Hydrology and Rehabilitation. 2009; 7(1): 68-102.

7. Carvalho LAC, Lopes JPPB, Kaihami GH, Silva RP, Bruni-Cordoso A, Baldini RL, Meotti FC. Uric acid disrupts hypochlorous acid production and bactericidal activity of HL-60 cells. Redox Biology. 2018; 16: 179-188.

8. Cinel I, Gür S. Direct inotropic effects of propofol and adenosine on rat atrial muscle: possible mechanisms. Pharmacol Res. 2000; 42(2): 123-128.

9. Climaco-Arvizu S, Domínguez-Acosta O, Cabañas-Cortés MA, et al. Aryl hydrocarbon receptor influences nitric oxide and arginine production and alters M1/M2 macrophage polarization. Life Sci. 2016; 155: 76-84.

10. Díaz-Díaz CJ, Ronnekleiv-Kelly SM, Nukaya M, et al. The Aryl Hydrocarbon Receptor is a Repressor of Inflammation-associated Colorectal Tumorigenesis in Mouse. Ann Surg. 2016; 264(3): 429-436.

11. Douglas SD, Quie PG. Investigation of Phagocytes in Disease. Churchil; 1981: $110 \mathrm{p}$.

12. Esser $\mathrm{C}$, Rannug A. The aryl hydrocarbon receptor in barrier organ physiology, immunology, and toxicology. Pharmacol Rev. 2015; 67(2): 259-279.

13. Gao L, Jiang Y, Wang Y, Qu X, Li L, Lou X, Wang Y, GuoW, Liu Y. Male asymptomatic hyperuricemia patients display a lower number of NKG2 ${ }^{+}$NK cells before and after a lowpurine diet. Medicine (Baltimore). 2018; 97(50): e13668.

14. Ghaemi-Oskouie F, Shi Yan. The role of uric acid as an endogenous danger signal in immunity and inflammation. Curr Rheumatol Rep. 2011; 13(2): 160-166.

15. Goryachkovskiy AM. Clinical Biochemistry [in Russian]. Odesa: Astroprint; 1998: 608 p. 
16. Gozhenko AI. Functional-metabolic continuum [in Russian]. J of NAMS of Ukraine. 2016; 22 (1): 3-8.

17. Gozhenko AI, Smagliy VS, Korda IV, Badiuk NS, Zukow W, Popovych IL. Functional relationships between parameters of uric acid exchange and immunity in female rats. Actual problems of transport medicine. 2019; 4(58): 123-131.

18. Gozhenko AI, Smagliy VS, Korda IV, Badiuk NS, Zukow W, Popovych IL. Features of immune status in different states of uric acid metabolism in female rats. Journal of Education, Health and Sport. 2019; 9(12): 167-180.

19. Gozhenko AI, Smagliy VS, Korda IV, Badiuk NS, Zukow W, Kovbasnyuk MM, Popovych IL. Relationships between parameters of uric acid exchange and immunity as well as microbiota in patients with neuroendocrine-immune complex dysfunction. Journal of Education, Health and Sport. 2020; 10(1): 165-175.

20. Gozhenko AI, Smagliy VS, Korda IV, Badiuk NS, Zukow W, Kovbasnyuk MM, Popovych IL. Relationships between changes in uric acid parameters metabolism and parameters of immunity and microbiota in patients with neuroendocrine-immune complex dysfunction. Journal of Education, Health and Sport. 2020; 10(2): 212-222.

21. Gozhenko AI, Zukow W, Polovynko IS, Zajats LM, Yanchij RI, Portnichenko VI, Popovych IL. Individual Immune Responses to Chronic Stress and their Neuro-Endocrine Accompaniment. RSW. UMK. Radom. Torun; 2019: 200 p.

22. Hoskin DW, Mader JS, Furlong SJ, Conrad DM, Blay J. Inhibition of T cell and NK cell function by adenosine and its contribution to immune evasion by tumor cells (Review). Int $\mathrm{J}$ Oncol. 2008; 32(3): 527-535.

23. Huang S, Apasov S, Koshiba M, SitkovskiM. Role of $A_{2 A}$ extracellular adenosine receptor mediated signaling in adenosine mediated inhibition of of T-cell activation and expansion. Blood. 1997; 90(4): 1600-1610.

24. Jondal M, Holm G, Wigzell H. Surface markers on human T and B lymphocytes. I. A large population of lymphocytes forming nonimmune rosettes with sheep red blood cells. J Exp Med. 1972; 136(2): 207-215.

25. Khaitov RM. Physiology of immune system [in Russian]. Moskva: VINITI RAN; 2005: 428 p.

26. Limatibul S, Shore A, Dosch HM, Gelfand EW. Theophylline modulation of E-rosette formation: an indicator of T-cell maturation. Clin Exp Immunol. 1978; 33(3): 503-513.

27. Martínez-Reyes CP, Manjarrez-Reyna AN, Méndez-García LA, et al. Uric Acid Has Direct Proinflammatory Effects on Human Macrophages by Increasing Proinflammatory Mediators and Bacterial Phagocytosis Probably via URAT1. Biomolecules. 2020; 10(4): 576.

28. Monahan TS, Sawmiller DR, Fenton RA, Dobson JG Jr. Adenosine A(2a)-receptor activation increases contractility in isolated perfused hearts. Am J Physiol Heart Circ Physiol. 2000; 279(4): H1472-H1481.

29. Morelli M, Carta AR, Kachroo A, Schwarzschild A. Pathophysiological roles for purines: adenosine, caffeine and urate. Prog Brain Res. 2010; 183: 183-208.

30. Navalta JW, Fedor EA, Schafer MA, Lyons TS, Tibana RA, Pereira GB, Prestes J. Caffeine affects $\mathrm{CD}^{+}$lymphocyte differently in naïve and familiar individuals following moderate intensity exercise. Int J Immunopathol Pharmacol. 2016; 29(2): 288-294.

31. Perederiy VG, Zemskov AM, Bychkova NG, Zemskov VM. Immune status, principles of its evaluation and correction of immune disorders [in Russian]. Kyiv. Zdorovya; 1995: 211 p.

32. Phelan D, Winter GM, Rogers WJ, Lam JC, Denison MS. Activation of the Ah receptor signal transduction pathway by bilirubin and biliverdin. Arch Biochem Biophys. 1998; 357(1): 155163.

33. Popadynets' OO, Gozhenko AI, Zukow W, Popovych IL. Relationships between the entropies of EEG, HRV, immunocytogram and leukocytogram. Journal of Education, Health and Sport. 2019; 9(5): 651-666.

34. Popovych IL. Functional interactions between neuroendocrine-immune complex in males rats [in Ukrainian]. Achievements of Clinical and Experimental Medicine. 2008; 2(9): 80-87.

35. Pousti A, Deemyad T, Malihi G. Mechanism of inhibitory effect of citalopram on isolated guinea-pig atria in relation to adenosine receptor. Hum Psychopharmacol. 2004; 19(5): 347350 . 
36. Quintana FJ, Sherr DH. Aryl hydrocarbon receptor control of adaptive immunity. Pharmacol Rev. 2013; 65(4): 1148-1161.

37. Smagliy VS, Gozhenko AI, Korda IV, Badiuk NS, Zukow W, Kovbasnyuk MM, Popovych IL. Variants of uric acid metabolism and their immune and microbiota accompaniments in patients with neuroendocrine-immune complex dysfunction. Actual problems of transport medicine. 2020; 1(59): 114-125.

38. Sternberg EM. Neural regulation of innate immunity: a coordinated nonspecific host response to pathogens. Nat Rev Immunol. 2006; 6(4): 318-328.

39. Thayer JF, Sternberg EM. Neural aspects of immunomodulation: Focus on the vagus nerve. Brain Behav Immun. 2010; 24(8): 1223-1228.

40. Tracey KJ. Reflex control of immunity. Nat Rev Immunol. 2009; 9(6): 418-428.

41. Uchakin PN, Uchakina ON, Tobin BV, Ershov FI. Neuroendocrine immunomodulation [in Russian]. Vestnik Ross AMN. 2007; 9: 26-32.

42. Vigano S, Alatzoglou D, Irving M, Menetrier-Caux Ch, Caux Ch, Romero P, Coukos G. Targeting adenosine in cancer immunotherapy to enhance T-cell function. Front Immunol. 2019; 10: 925.

43. Yang X, Liu H, Ye T, et al. AhR activation attenuates calcium oxalate nephrocalcinosis by diminishing M1 macrophage polarization and promoting M2 macrophage polarization. Theranostics. 2020; 10(26): 12011-12025.

44. Zajats LM, Polovynko IS, Zukow W. Features neuro-endocrine support diversity of immune responses to chronic stress in male rats. Journal of Education, Health and Sport. 2017; 7(3): $97-105$. 